\title{
An Examination Of Personal Values And Value Systems Of Chinese And U.S. Business Students
}

Don E. Giacomino, Ph.D., Marquette University, USA

Xin Li, M.A., PhD Candidate, Beijing Institute of Technology, China

Michael D. Akers, Ph.D., Marquette University, USA

\begin{abstract}
Using the Rokeach Value Survey and the Musser and Orke typology this paper examines the personal values and value systems of business students in China and compares the results with the results of a recent study that used similar methodology to examine the values and value systems of U.S. students. The study also examines the differences in values and value systems of the Chinese students by gender and by major. While there are few differences for the Chinese students by gender, our findings show several differences in the rankings of values by the Chinese and U.S. students as well as differences in value systems. Implications for accounting education are discussed.
\end{abstract}

Keywords: Ethics; Values; Value Systems; Chinese Students; Musser; Orke

\section{INTRODUCTION}

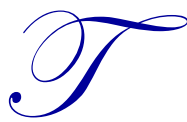

his study measures personal values and value systems of Chinese business students and compares the findings with a recent study of U.S. business students. We also compare our findings with a prior study that examined the values and value systems of Chinese students. While values have been defined in several ways by researchers, the common view in values research is that values influence behavior. For example Rokeach $(1973,16)$ describes values as "enduring beliefs that a specific mode of conduct or end-state of existence is personally or socially preferable to an opposite or converse mode of conduct or end-state of existence".

As a result of the numerous financial frauds that have occurred during the past two decades, there has been increased interest in moral and ethical behavior by businesses, professional organizations and academic institutions. In addition to a code of conduct, which should guide the behavior of employees, many organizations have adopted whistleblowing policies and procedures, as an element of internal control, to provide employees with a mechanism to report unethical behavior. Professional organizations, such as the American Institute of Certified Public Accountants and State Boards of Accountancy now require continuing education in the area of ethics. The curricula at most business schools have changed as there is a greater emphasis on ethical conduct in business courses.

Values of university business majors are important to study because these students represent the future leaders of organizations. Since the personal values of these students will influence their behavior and determine the direction of businesses and other organizations in our society, it is useful to learn more about their values. Also, as more schools are recruiting and admitting students from China, it is important to understand if the values of the Chinese students differ from the U.S. students.

While there has been considerable research on the values of college students (accounting and business) in the United States, less research has been conducted on the values of college students, particularly accounting students and business students, in China. This paper continues with a review of research that examined the personal values of Chinese college students. In section two we describe the sample and methodology used in our study. Next, 
we interpret and summarize the results followed by comments regarding the limitations of the study and recommendations for future research.

\section{RESEARCH OVERVIEW}

We examine three studies that measured personal values of Chinese students and are relevant to this study. First, Matthews (2000) used the Chinese Values Survey (CVS), which was developed to complement the research instruments developed by Rokeach (1973) and Schwartz (1992). That study surveyed Chinese students who were attending three separate Australian universities. Matthews used factor analysis to identify the following four factors from the forty values measured: 1) Integrity \& Tolerance-Development of self; 2) Confucian Ethos-Relationships with others; 3) Loyalty to ideals \& humanity-social responsibility; 4) Moderation \& moral discipline-worldly wisdom.

Second, Lan et. al. (2009) used the Schwartz (1992) survey to measure the personal values and value systems of Chinese accounting practitioners (454) and graduate accounting students (126). They found that the male accounting students rated the value system Achievement significantly higher than the female students. There were also eleven significant gender differences in personal values of the students. The males placed more importance on Creativity, Authority, Social Justice, Ambitious, Daring, Influential, Responsible, and Successful while the females place more importance on Pleasure, Mature Love and Healthy.

Third, Wang and Juslin (2012) surveyed students at three separate Chinese universities to examine the link between Chinese students' values and perceptions of Corporate Social Responsibility issues (CSR). They assessed personal values by using an instrument based on the Schwartz Values Questionnaire (SVQ) (Schwartz, 1994). The instrument used to evaluate the perception of CSR performance was based on current literature and the Sustainability Reporting Guideline, a global framework for sustainability reporting, with emphasis on economic, social and environmental dimensions (Wang and Juslin, 2012). Their findings showed that females demonstrated more ethical values than male students and females had more a negative perception of CSR performance.

\section{SAMPLE AND METHODOLOGY}

Using the Rokeach (1973) Value Survey (RVS), we surveyed 200 Chinese business students (undergraduate and graduate) at Beijing Institute of Technology. The survey was provided to the students in both Chinese and English. Students completed the survey during class or a subsequent break. The undergraduate students were juniors and seniors, while the graduate students were in the MSA and MBA programs. We determined the students' value systems by applying the Musser and Orke (1992) methodology to the survey results. The findings of this study were compared with a recent study (Giacomino et al. 2011) that used the same methodology to examine the values and value systems of U.S. students.

The Rokeach Value Survey (RVS) is a classification system that has two sets of values, 18 individual value items in each set (See Table 1). One set is called terminal values, the other instrumental values. RVS is based on a 1968 volume (Beliefs, Attitudes, and Values) which presented the philosophical basis for the association of fundamental values with beliefs and attitudes. Terminal Values refer to desirable end-states of existence. These are the goals that a person would like to achieve during his or her lifetime. These values vary among different groups of people in different cultures. Instrumental Values refer to preferable modes of behavior. Participants in the survey rank the 18 values in each set in order of importance to them, with 1 being most important and 18 being least important. Following is a classification of the values in the RVS: 
Table 1

Personal Values Survey

Instructions: Please rank the values in each of the two sets from 1 to 18

(1 means most important and 18 means least important). As guiding principles in your life. No ties please.

\begin{tabular}{|c|c|c|c|}
\hline Set A Values & Rank & Set B Values & Rank \\
\hline A Comfortable Life (Prosperous Life) & & Ambitious (Hardworking, Aspiring) & \\
\hline Equality (Brotherhood \& Equal Opportunity) & & Broad-minded (Open-minded) & \\
\hline An Exciting Life (Stimulating, Active Life) & & Capable (Competent; effective) & \\
\hline Family Security (Taking care of loved ones) & & Clean (Neat and tidy) & \\
\hline Freedom (Independence and free choice) & & Courageous (Standing up for your beliefs) & \\
\hline Health (Physical and mental well-being) & & Forgiving (Willing to pardon others) & \\
\hline Inner Harmony (Freedom from inner conflict) & & Helpful (Working for the welfare of others) & \\
\hline Mature Love (Sexual and spiritual intimacy) & & Honest (Sincere and truthful) & \\
\hline National Security (Protection from attack) & & Imaginative (Daring and creative) & \\
\hline Pleasure (An enjoyable, leisure life) & & Independent (Self-reliant; self-sufficient) & \\
\hline Salvation (Saved; eternal life) & & Intellectual (Intelligent and reflective) & \\
\hline Self-respect & & Logical (Consistent; rational) & \\
\hline A Sense of Accomplishment (lasting contribution) & & Loving (Affectionate and tender) & \\
\hline Social Recognition (Respect and admiration) & & Loyal (Faithful to friends or the group) & \\
\hline True Friendship (Close companionship) & & Obedient (Dutiful; respectful) & \\
\hline Wisdom (A mature understanding of Life) & & Polite (Courteous and well-mannered) & \\
\hline A World at Peace (World free of war and conflict) & & Responsible (Dependable and reliable) & \\
\hline A World of Beauty (Beauty of nature and the arts) & & Self-controlled (Restrained; self-disciplined) & \\
\hline AGE: ___ Gender: Female __ Male __ & MAJOR: & $\mathrm{ACCO}_{-} \mathrm{ECON}$ & \\
\hline
\end{tabular}

TERMINAL VALUES (end-states)

$\begin{array}{ll}\text { Social (focus on others) } & \text { Personal (self-focused) } \\ \text { A World at Peace } & \text { A Comfortable Life } \\ \text { A World of Beauty } & \text { An Exciting Life } \\ \text { Equality } & \text { A Sense of Accomplishment } \\ \text { Family Security } & \text { Health } \\ \text { Freedom } & \text { Inner Harmony } \\ \text { Mature Love } & \text { Pleasure } \\ \text { National Security } & \text { Salvation } \\ \text { Social Recognition } & \text { Self-respect } \\ \text { True Friendship } & \text { Wisdom }\end{array}$

INSTRUMENTAL VALUES (behavioral)

\begin{tabular}{ll} 
Moral (moral means to achieve goals) & Competence (focus on competence) \\
\cline { 1 - 2 } Broadminded & Ambitious \\
Forgiving & Capable \\
Helpful & Clean \\
Honest & Courageous \\
Loving & Imaginative \\
Loyal & Independent \\
Obedient & Intellectual \\
Polite & Logical \\
Responsible & Self-Controlled
\end{tabular}

Using the personal values survey instrument by Rokeach (1973), Musser and Orke (1992) developed a methodology for classifying people by value system. Musser and Orke indicate that people possessing the different value systems described in the matrix (Table 3) behave quite differently, as follows:

- $\quad$ Virtuous Advocates (i.e., virtue leaders) are more concerned about helping the team reach its goals than seeking their own personal goals. Such leaders help the team/organization reach its goals by being sensitive to the needs and feelings of their associates. This other-centered, other-sensitive focus exhibits trust and integrity to colleagues which allows them to take more risks and to become innovative. The 
Musser and Orke validation study identified Mother Teresa and Mahatma Gandhi as people who have a value system consistent with virtuous advocates.

- Independent Maximizers are more concerned about their own goals than those of the team or organization. They often ignore the needs and feelings of associates as their focus is on their personal goals. Independent maximizers are often viewed with a great deal of suspicion and mistrust. Consequently, associates are unwilling to take risks and eventually become stagnant. Donald Trump and Ivan Boesky, per the Musser and Orke validation study, have an independent maximizer value system.

- $\quad$ Honorable Egoists try to be sensitive to the needs and feelings of their associates in the process; however they seek to reach their own goals first. Thus, associates also tend to view these people with suspicion because of the leader's focus on personal goals rather than team or organizational goals. Associates aren't confident enough about their leader's motives to increase risk-taking and innovativeness. Arsenio Hall is a person with an honorable egoist value system, according to the Musser and Orke study.

- $\quad$ Effective Crusaders are more concerned about the team's or organization's goals than their own personal goals. While such leaders help their associates reach team goals, their approach is insensitive and ignores associates' needs and feelings. As a result, associates often find themselves in a love-hate relationship with these leaders. They want to love them because their heart is in the right place (reaching team goals) but the leader's insensitivity results in hurt and alienation. Thus, associates are reluctant to take chances and be more innovative. According to Musser and Orke, Oliver North has characteristics that fit the effective crusader value system. Table 3 shows the value system, concern (others, self), emphasis (competence vs. moral; personal vs. social goals) and person associated with each value system.

While the Musser and Orke methodology (reliability and scoring) has been discussed in prior research, we provide an overview to facilitate a review of the results. Musser and Orke found that these associations yielded good inter-rater reliability (Chi Square of 479.097, with $\mathrm{p}<.001$ ). They conducted three separate studies to determine the usefulness of their typology. They established midlines for their Value System Matrix by using the mean coordinate scores for a sample of students from three different colleges. Given a subject's scores on the terminal and instrumental coordinates, they assigned the respondent to one of four systems of value systems (or sets). As Musser and Orke state "Although this scoring procedure treats ordinal data with interval-ratio procedures, with differences in value preferences scaled equally, this need not be fatal to the analysis." Williams (1968) points out that it is rare for a person's behavior to be guided only by one or two particular values. As situations vary, diverse clusters of values are called into play." To further validate their scoring procedure, Musser and Orke used SPSS Quick Cluster for a sample of 277 students. They observe that subjects falling into the same cluster quadrants do not necessarily display identical rank orderings of individual values, "The subject's classification is a product of his or her overall preference for the 'systems' of Rokeach's values, not his or her preference for a specific value. The proposed typology allows a considerable degree of individuality within each value system.”

\section{RESULTS}

Of the 200 Chinese students that completed our survey, 197 indicated their major. Following is a breakdown of those 197 Chinese students:

\begin{tabular}{|c|c|c|c|c|c|}
\hline Undergraduates & $\#$ & Percent & Graduates & \# & $(\%)$ \\
\hline Accounting & 56 & $43 \%$ & Accounting & 29 & $44 \%$ \\
\hline Marketing & 39 & $30 \%$ & MBA & $\underline{37}$ & $\underline{56 \%}$ \\
\hline Public Management & 22 & $17 \%$ & Total & 66 & $100 \%$ \\
\hline Economics & 11 & $8 \%$ & & & \\
\hline Double Major & $\underline{3}$ & $2 \%$ & & & \\
\hline Total & $\overline{131}$ & $100 \%$ & & & \\
\hline
\end{tabular}

For the respondents that indicated their gender, the breakdown is $122(63 \%)$ female and $73(37 \%)$ male. 


\section{Values Rankings}

Tables 2 and 3 show the results for both surveys. Table 2 compares the rankings of personal values and Table 3 shows how the students fit into the value system matrix. First, let's look at the differences ("gap" column) in ranking of terminal values. Chinese and U.S. students give the same rank to two values, A Comfortable Life $\left(\right.$ ranked $4^{\text {th }}$ ) and An Exciting Life (ranked $16^{\text {th }}$ ). Both groups rank Family Security very high. U.S. students ranked the value first and Chinese students ranked it second. The largest differences are for Freedom (Chinese students ranked this value as 11 ranks more important) and National Security (Chinese students ranked this value nine ranks less important). Chinese students also ranked Health (seven ranks more important), Wisdom (six ranks more important) and Mature Love (six ranks more important) much higher than did U.S. students. U.S. students showed higher (than Chinese students) rankings for Inner Harmony (six ranks more important), Pleasure (five ranks more important) and Equality (five ranks more important). The high ranking of Health, Family Security and the low ranking of Salvation, An Exciting Life and Social Recognition are consistent with the Lan et al. (2009) findings.

Table 2

Rankings of Values Chinese and U.S. Students

\begin{tabular}{|c|c|c|c|}
\hline Set A (TERMINAL) & U.S. & China & Gap \\
\hline Family Security & 1 & 2 & 1 \\
\hline True Friendship & 2 & 6 & 4 \\
\hline Pleasure & 3 & 8 & 5 \\
\hline A Comfortable Life & 4 & 4 & 0 \\
\hline Inner Harmony & 5 & 11 & 6 \\
\hline National Security & 6 & 15 & 9 \\
\hline Equality & 7 & 12 & 5 \\
\hline Health & 8 & 1 & 7 \\
\hline Self-respect & 9 & 5 & 4 \\
\hline Social Recognition & 10 & 13 & 3 \\
\hline A Sense of Accomplishment & 11 & 10 & 1 \\
\hline Salvation & 12 & 18 & 6 \\
\hline Wisdom & 13 & 7 & 6 \\
\hline Freedom & 14 & 3 & 11 \\
\hline Mature Love & 15 & 9 & 6 \\
\hline An Exciting Life & 16 & 16 & 0 \\
\hline A World at Peace & 17 & 14 & 3 \\
\hline A World of Beauty & 18 & 17 & 1 \\
\hline Set B (INSTRUMENTAL) & $\underline{\text { U.S. }}$. & China & Gap \\
\hline Honest & $\overline{1}$ & 2 & 1 \\
\hline Ambitious & 2 & 13 & 11 \\
\hline Responsible & 3 & 1 & 2 \\
\hline Loyal & 4 & 8 & 4 \\
\hline Intellectual & 5 & 5 & 0 \\
\hline Courageous & 6 & 11 & 5 \\
\hline Logical & 7 & 15 & 8 \\
\hline Independent & 8 & 6 & 2 \\
\hline Loving & 9 & 9 & 0 \\
\hline Capable & 10 & 4 & 6 \\
\hline Broad-minded & 11 & 3 & 8 \\
\hline Self-controlled & 12 & 10 & 2 \\
\hline Polite & 13 & 12 & 1 \\
\hline Helpful & 14 & 16 & 2 \\
\hline Forgiving & 15 & 7 & 8 \\
\hline Obedient & 16 & 18 & 2 \\
\hline Imaginative & 17 & 14 & 3 \\
\hline Clean & 18 & 17 & 1 \\
\hline
\end{tabular}


Table 3

Value Systems Matrix

U.S. and Chinese Business Students

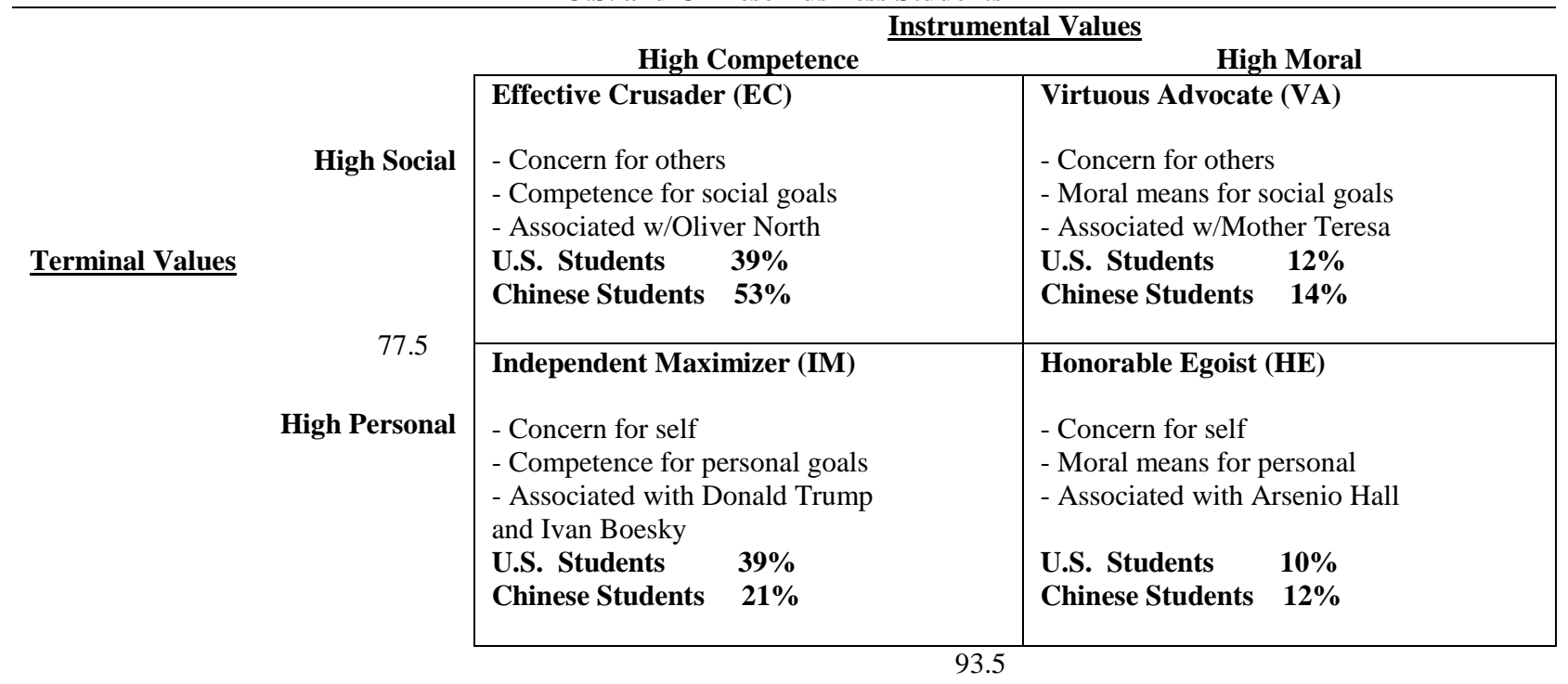

We examine the major differences ( $>4$ ranks) in the terminal values to provide further insights regarding the differences between Chinese and U.S. students. While China has gone through significant economic and political reforms since 1978, many Chinese believe the government still limits citizens' freedom in many ways. Our findings suggest that Chinese students are longing for more freedom while U.S. students might take freedom for granted. The difference in national security might result from the fact that the last war for China, which was with Vietnam, concluded in 1979 while the September 11, 2001 attack on the United States, combined with the wars involving Afghanistan and Iraq, are still very real for the U.S. students. The Chinese place high importance on health as this is seen as the basis for other values such as family security and comfortable life. Despite renewed attention to healthy foods in the U.S., obesity continues to be a problem, particularly with high school and college students. While salvation was in the bottom half (12) by U.S. students this value was ranked last by Chinese students. This finding is not surprising since the U.S. students attend a Catholic institution and Chinese students are educated with a materialistic and dialectic philosophy. Most Chinese are atheists, thus salvation is a foreign concept to them. Considering the importance of the family in China, lower divorce rate in China as compared to the U.S., and the view on premarital sex (traditional Chinese believe sexual relations should be with only one man and this occurs after marriage). In the Chinese culture, wisdom is considered a desirable value as they believe their leaders must have wisdom to deal with difficulties and guide the nation successfully. The lower ranking of inner harmony and pleasure by the Chinese students is not surprising. Confucianism focuses on the group rather than the individual, even if self-interests must be sacrificed. Chinese students learn at an early age that hard work, not enjoyment or pleasure, is necessary to become successful.

For instrumental values, the gap (rank differences) between U.S. and Chinese students is much smaller. Chinese and U.S. students give the same rankings to Intellectual $\left(5^{\text {th }}\right)$ and Loving $\left(9 .^{\text {th }}\right)$. Both student groups rank these values high; Honest (U.S. $1^{\text {st }}$, Chinese $2^{\text {nd }}$ ) and Responsible (U.S. $3^{\text {rd }}$, Chinese $1^{\text {st }}$ ). They rank Polite, Independent (U.S. $8^{\text {th }}$, Chinese $6^{\text {th }}$ ), and Self-controlled (U.S. $12^{\text {th }}$, Chinese $10^{\text {th }}$ ) near the middle and the values Polite (U.S. 13 ${ }^{\text {th }}$, Chinese $12^{\text {th }}$ ), Helpful (U.S. 14 ${ }^{\text {th }}$, Chinese $16^{\text {th }}$ ), Obedient (U.S. 16 ${ }^{\text {th }}$, Chinese $18^{\text {th }}$ ), and Imaginative (U.S. $17^{\text {th }}$, Chinese 14th) near the bottom. Of the 18 values, there are rank differences of four or more for seven of the values. The largest difference is where U.S. students rank the value, Ambitious, 11 ranks higher than the Chinese students. The Chinese culture is hierarchical with five predominant relationships (ruler-subject, father-son, husband-wife, elder and younger brothers, older and younger friends). Ambition focuses on personal achievement and is contradictory to this hierarchical mentality. 
The next highest differences (eight ranks) are for the values Broad-minded (Chinese students give higher ranking), Forgiving (Chinese students rank higher) and Logical (U.S. students rank higher). The reform in China during the past 30 years suggests that the Chinese value being broadminded, as compared to the environment prior to the 1980 's-highly planned economy and political system similar to North Korea with rigid ideology. Since forgiveness is a major component of Confucianism, our findings aren't surprising. While both the U.S. and China have laws and regulations, such laws and regulations are often changed and abused by officers of the government in China, thus mitigating the logical process that should exist. Accordingly, the Chinese often rely upon complex connections, referred to as Guangxi, to conduct business. Such connections don't necessarily reflect a logical process. As previously discussed, Chinese parents instill at an early age the importance of hard work and competition, since resources aren't as abundant in China as they are in the U.S. In order to be competitive, Chinese students must be capable. The high ranking of the value, Capable, is consistent with the Lan et al. (2009) findings.

The Chinese consider courageous related to action as compared to strategy and wisdom. The Art of War, one of the oldest and most successful books on military strategy, which has had considerable influence on Easternmilitary thinking, indicates that the best strategy for winning a war is to do it without fighting. The lower rank of this value by the Chinese students is consistent with this rationale. While there is a gap of four ranks between China and U.S students, this is primarily due to the fact that female Chinese students ranked this value much lower than did male Chinese students. We believe the Chinese female students ranked the value, Loyal, lower because females take a secondary and supporting role in China. It is expected of them. Loyalty is an expectation and not an option. Accordingly, loyalty is not a value that they rank high.

\section{Musser-Orke Matrix}

For our study, we used the scoring procedure developed by Musser and Orke. While the methodology has been discussed in prior research, we provide an overview to facilitate a review of the results. The procedure is as follows:

- $\quad$ For each set of values, terminal and instrumental (ends and means), we total the rankings of the following values in the terminal values group: Equality, Family Security, Freedom, Mature Love, National Security, Social Recognition, True Friendship, A World at Peace and A World of Beauty. These values comprise the social terminal values. The score for these values is determined by subtracting the total rankings from 171 (the sum of rankings for all values in the set). This method is equivalent to assigning the highest-rated value a score of 18 and the lowest-rated value a score of 1 . For example, if the sum of the rankings for the terminal were 87, then the score for the social terminal set of values would be 84 (171-87). Personal terminal values consist of the remaining terminal values. The score for the personal terminal values would be 87 . Thus, for these assumed rankings the respondent's value set would be placed in the lower portion of the Value System Matrix.

- $\quad$ To determine the score for instrumental value, we use the same procedure as for (a) above. The values included in the moral instrumental set are; Broadminded, Forgiving, Helpful, Honest, Loving, Loyal, Obedient, Polite and Responsible. The sum of the rankings for those values is then subtracted from 171 to get the moral competence score. If the respondent's rankings for these values were to total 72 , then the moral competence score would be 99 (171-72). This score would put the respondent in the right portion of the Value System Matrix.

- Musser and Orke established and validated their cutoff scores (mean score) for terminal values as 77 and instrumental values as 93. Using their methodology, we established cutoff scores/lines in the Value System Matrix as 77.5 and 93.5. Therefore, using the assumed rankings from parts (a) and (b) above, the respondent (84 on the terminal axis and 99 on the instrument axis) would be classified in the Honorable Egoist (lower right) quadrant of the Value System Matrix.

Table 3 shows data for classifying students by value system. Results for Virtuous Advocate (12\% U.S. and 14\% Chinese) and Honorable Egoist (10\% U.S. and 12\% Chinese) are very close for the two student groups. Both student groups show high emphasis on moral means. Thus, the U.S. and Chinese students are very close in this regard. However, we see large differences for Effective Crusader and Independent Maximizer. Over half (53\%) of the Chinese students are classified as Effective Crusaders as opposed to 39\% for U.S. students. Both of these value 
systems place an emphasis on competence. There is an $18 \%$ difference (U.S. 39\% and Chinese 21\%) for Independent Maximizer; showing U.S. students have higher personal (vs. social) goals than the Chinese students. Since the Chinese are more focused on the attainment of group goals, as compared to individual goals, this result is not surprising.

Table 4 shows the results by gender for rankings of values. Gender differences are small. For the terminal values, values rankings by females and males were quite close (for 12 of the 18 values, rankings were the same or only one rank different). Females and males differed by four or more ranks on only two values; Inner Harmony (females five ranks higher) and A Sense of Accomplishment (females four ranks lower). Differences in Instrumental rankings are also very small by gender. Males rank Independent lower (five ranks) in importance than do the females and females rank Loyal (five ranks lower) much less in importance than do the males. Thus, we see that female and male Chinese students are very close in terms of their desired end states (terminal values) and in the means (instrumental values) for reaching those end states.

Table 4

Rankings of Values

Female and Male Chinese Students

\begin{tabular}{|c|c|c|c|}
\hline Set A (TERMINAL) & M (37\%) & F (63\%) & Gap \\
\hline Family Security & $\frac{1}{1}$ & $\frac{2}{2}$ & $\frac{1}{1}$ \\
\hline Health & 2 & 1 & 1 \\
\hline Freedom & 3 & 3 & 0 \\
\hline A Comfortable Life & 4 & 4 & 0 \\
\hline True Friendship & 5 & 7 & 2 \\
\hline Self-respect & 6 & 5 & 1 \\
\hline A Sense of Accomplishment & 7 & 11 & 4 \\
\hline Wisdom & 8 & 6 & 2 \\
\hline Mature Love & 9 & 10 & 1 \\
\hline Pleasure & 10 & 9 & 1 \\
\hline Social Recognition & 11 & 13 & 2 \\
\hline Equality & 12 & 12 & 0 \\
\hline Inner Harmony & 13 & 8 & 5 \\
\hline A World at Peace & 14 & 15 & 1 \\
\hline An Exciting Life & 15 & 16 & 1 \\
\hline A World of Beauty & 16 & 17 & 1 \\
\hline National Security & 17 & 14 & 3 \\
\hline Salvation & 18 & 18 & 0 \\
\hline Set B (INSTRUMENTAL) & Male & Fem & Gap \\
\hline Responsible & $\frac{1}{1}$ & 1 & 0 \\
\hline Honest & 2 & 3 & 1 \\
\hline Broad-minded & 3 & 2 & 1 \\
\hline Capable & 4 & 4 & 0 \\
\hline Loyal & 5 & 10 & 5 \\
\hline Intellectual & 6 & 6 & 0 \\
\hline Self-controlled & 7 & 9 & 2 \\
\hline Forgiving & 8 & 7 & 1 \\
\hline Loving & 9 & 8 & 1 \\
\hline Independent & 10 & 5 & 5 \\
\hline Courageous & 11 & 11 & 0 \\
\hline Polite & 12 & 12 & 0 \\
\hline Ambitious & 13 & 13 & 0 \\
\hline Logical & 14 & 15 & 1 \\
\hline Imaginative & 15 & 14 & 1 \\
\hline Helpful & 16 & 16 & 0 \\
\hline Clean & 17 & 17 & 0 \\
\hline Obedient & 18 & 18 & 0 \\
\hline
\end{tabular}


Table 5 shows values systems by gender for value systems. Males have higher percentages as Effective Crusaders (58\% vs. $49 \%$ ) and Virtuous Advocates (16\% vs. 13\%), but lower percentage as Independent Maximizers $(19 \%$ vs. $23 \%)$ and Honorable Egoists (7\% vs. $15 \%)$. Since the two upper quadrants signify service toward others, these results are somewhat surprising. The U.S. study (Giacomino et al. 2011) found female students showing greater emphasis on serving others. Thus, our results indicate that Chinese males and U.S. women place emphasis on others rather than on themselves. This might be attributed to the change in women's social status in China. Historically, the social status of women was low and they didn't have many social rights. Even today, many women in rural areas still face discrimination. Women have traditionally been responsible for taking care of the family, but that has changed as many women are now working while still raising the family and men are taking on more of the social responsibility.

Table 5

Value Systems Matrix

Chinese Business Students by Gender

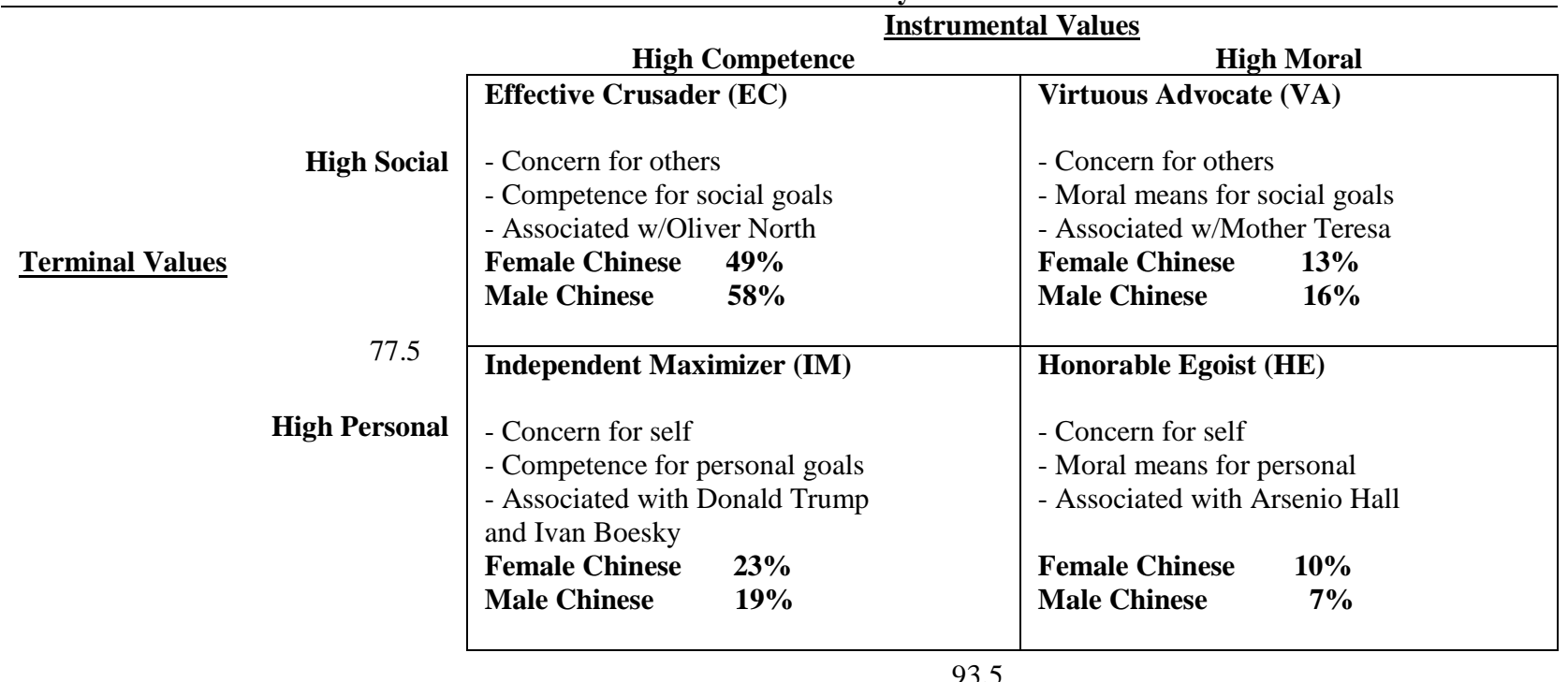

\section{Limitations}

This study has four inherent limitations. The samples in the study of Chinese students and the U.S. study may not be representative of all business majors in the U.S. or in China. First, the sample was not randomly selected. All of student participants were from the same institution which is a large public university in China. Secondly, the U.S study also used students from one institution which is a mid-western, faith-based, private university. Third, while this study and the U.S. study were conducted at approximately the same time, both were not conducted simultaneously which could impact the comparisons.

\section{Contributions and Implications}

This study makes three major contributions to the literature. Frist, this study provides additional data regarding the values of Chinese students. This is important as the number of Chinese students attending U.S. institutions continues to increase. Second, an understanding of the differences between Chinese and U.S. students will help U.S. faculty to more fully understand the interactions between the two groups and how these differences impact the dynamics of a class, such class discussion or the formation of groups. Third, for faith-based institutions, an understanding of how the values of the institution might differ from the Chinese students will be helpful in interacting and relating to these students. Fourth, this study adds to the generational values literature by providing data for current Chinese students. 


\section{Future Research}

Future research should continue to examine the values of Chinese accounting and other business students to determine changes in their values and the reasons why. Since prior research (Lan, et al., 2008) suggests that western values have impacted Chinese students, future research could examine the level of narcissism exhibited by Chinese business students, specifically accounting students.

\section{AUTHOR INFORMATION}

Dr. Don E. Giacomino, CPA, Professor and Flynn Chair Holder, Department of Accounting, College of Business Administration, Straz Hall 303, Marquette University, Milwaukee, WI 53201 USA. E-mail: don.giacomino@marquette.edu

Xin Li, M.A., Ph.D. Candidate (Management), SME Lecturer, Department of Accounting, School of Management and Economics, Beijing Institute of Technology, Beijing, P.R. China. E-mail: Lixinsheila@bit.edu.cn

Michael D. Akers, CPA, CMA, CFE, CIA, Charles T. Horngren Professor and Department Chair Department of Accounting, College of Business Administration, Straz Hall 303, Marquette University, Milwaukee, WI 53201 USA. E-mail: michael.akers@ marquette.edu (Corresponding author)

\section{REFERENCES}

1. Giacomino, D. E., Michael D. Akers and Jill Brown. 2011. "Generational Differences of Personal Values of Business Students," American Journal of Business Education Volume 4, Number 9 (September 2011):19-30.

2. Lan, G., Z. Ma, J. Cao, and H. Zhang. 2009. "A Comparison of Personal Values of Chinese Accounting Practitioners and Students." Journal of Business Ethics. Vol. 88: 59-77.

3. Matthews, Barbara Marshall. 2000. "The Chinese Value Survey; An interpretation of value scales and consideration of some preliminary results." International Education Journal Volume 1, No 2 117-126.

4. $\quad$ Musser, Steven J. and Eric Orke. 1992. "Ethical Value Systems: A Typology.” The Journal of Applied Behavioral Science 28(3): 348-362.

5. $\quad$ Rokeach, M. 1973. The Nature of Human Values. New York, NY: Free Press.

6. Schwartz, S. H. 1992. "Universals in the Content and Structure of Values: Theoretical Advances and Empirical Tests in 20 Countries." Advances in Experimental Social Psychology. Academic Press.

7. Schwartz, S. H. 1994. "Are there universal aspects in the structure and contents of human values?" Journal of Social Issues 50(4), 19-45.

8. Wang, Lei and Heikki Juslin. 2012. "Values and Corporate Social Responsibility Perceptions of Chinese University Students." Journal of Academy Ethics 10. 57-82.

9. Williams, R.M. 1968. "Values.” In D.L. Sills (ed.), International Encyclopedia of the Social Sciences. New York: Macmillan, 287. 